\title{
Impact of Rice Nursery Nutrient Management, Seeding Density and Seedling Age on Yield and Yield Attributes
}

\author{
Bishnu Bilas Adhikari ${ }^{1}$, Biswarup Mehera ${ }^{2}$, Stephan Haefele ${ }^{3}$ \\ ${ }^{1}$ Institute of Agriculture and Animal Science (IAAS), Chitwan, Nepal; ${ }^{2}$ Sam Higginbottom Institute of Agriculture, Technology and \\ Sciences (SHIATS), Allahabad, India; ${ }^{3}$ The University of Adelaide (UOA), Adelaide, Australia. \\ Email: bishnu_adhi@yahoo.com, bmehera@rediffmail.com, Stephan.haefele@acpfg.com.au
}

Received November $22^{\text {nd }}, 2013$; revised December $23^{\text {rd }}, 2013$; accepted December $30^{\text {th }}, 2013$

Copyright (C) 2013 Bishnu Bilas Adhikari et al. This is an open access article distributed under the Creative Commons Attribution License, which permits unrestricted use, distribution, and reproduction in any medium, provided the original work is properly cited.

\begin{abstract}
To help farmers in the mid hills of Nepal improve their crop management and rice yields, we conducted a study testing different nursery management options and their effect on grain yield and yield components under rainfed conditions. The experiment was conducted in a farmer's field during the cropping season 2009 and 2010 at Sundarbazar, Lamjung, Nepal, using a 3-factor factorial RCB design with 3 replications. The three management factors tested were 1) fertilizer management in the nursery, 2) seeding density, and 3) seedling age at transplanting, using the rainfed lowland rice variety Radha-4. There were eight treatment combinations, consisting of two levels of fertilization $(0$ and 20:20:0:13 kg NPKS ha ${ }^{-1}$ at 15 DAS), two levels of seeding density (607 and $303 \mathrm{~g} \cdot \mathrm{m}^{-2}$ ) and two seedling ages (20 and 40 days old). Two years' results showed that top-dressed fertilizer in the nursery had no consistent effect on grain yield. However, lower seeding density $\left(303 \mathrm{~g} \cdot \mathrm{m}^{-2}\right)$ resulted in taller plants, more productive tillers $\mathrm{m}^{-2}$, less sterility and higher grain yield. In addition, older seedlings (40 days) produced taller plants, more productive tillers, more filled grains, and a higher grain and straw yield. The interaction analysis between both factors indicated that 40 days old seedling with a low seeding density produced the highest grain yield, both in the drought season 2009 and the high-yielding season 2010. The economic analysis confirmed that the treatment with low seeding density and 40 days old seedlings produced by far the highest net returns and B:C ratio in both seasons, independent of the fertilizer treatment. The combination of these two management components is therefore economically viable and profitable, and can be recommended to farmers. However, the results need to be confirmed for other varieties used by farmers in the region.
\end{abstract}

Keywords: Nepal; Net Return; Nursery Management; Rainfed Rice; Seeding Density; Seedling Age

\section{Introduction}

Rice (Oryza sativa L.) is the most important staple food crop in Nepal, followed by maize (Zea mays L.) and wheat (Triticum aestivum L.). It is grown in all agro ecological zones from the Terai plains to the high hills (up to $3050 \mathrm{~m}$ asl in Jumla district), including valleys, foot hills and mid hills of Nepal [1]. It is grown on about 1.5 million hectares and produced 5.07 million tons in the cropping season 2011/12, suggesting an average paddy yield of 3.31 tons $\cdot \mathrm{ha}^{-1}$ [2]. About $70 \%$ of the total Nepalese rice area is located in the Terai plains, $5 \%$ in the inner Terai, $23 \%$ in the mid-hills, and the remaining $2 \%$ in the high hills [3]. Rice contributes nearly $20 \%$ to the agricultural gross domestic product (AGDP) and provides more than $50 \%$ of the total calorie requirements of the Nepalese people [4].
Although rice is so important in Nepal and high yielding modern varieties are widespread, the average yield below the levels obtained in other rice producing countries remains. Consequently, there is a considerable gap in rice productivity between attainable yields and the yield in most farmers' fields. There are of course many reasons for this gap, and not all can be addressed by resourcepoor farmers. But often even basic crop management components like seedbed management are not optimized, and the importance of this initial crop management step is under estimated. Properly managed seedbeds with adequate plant nutrition, optimal seeding densities and use of seedlings at appropriate age are important factors to get vigorous plant stands after transplanting [5]. However, many Nepalese farmers are not giving high priority to the production of vigorous seedlings in their nurseries. 
Conventionally the mid hill farmers of Lamjung and Tanahun district are using very high seed rates (in average $607 \mathrm{~g} \cdot \mathrm{m}^{-2}$ ) in their nursery, resulting in non-vigorous seedlings, and they used 4 - 10 seedlings hill-1 at transplanting [6]. The yield and yield components of the rice crop are affected negatively by using high seed rates in the nursery [7]. By making a small investment in raising healthy and vigorous seedlings in the nursery, farmers could harvest an additional yield of up to $2 \mathrm{t} \cdot \mathrm{ha}^{-1}$ [8]. It is suggested to use $200 \mathrm{~g}$ of seeds per $\mathrm{m}^{2}$ as optimum for obtaining healthy vigorous seedlings that will perform better after transplanting [9].

The length and dry weight of seedlings, number and length of roots, and growth of seedlings increased significantly by increasing the fertility level in the nursery [10]. Increased seedling vigour and nutrient concentration in the rice plant during early growth stage were shown to be important for improving subsequent plant growth and final grain yield [11]. Using healthy and vigorous seedlings with sufficient nitrogenous fertilizers in the nursery resulted in more productive tillers and a higher grain yield, partly by better stress tolerance and decreased seedling mortality after transplanting $[8,12]$. Application of $\mathrm{N}$ and $\mathrm{P}$ in the rice nursery produced $50 \%$ and $100 \%$ more dry matter, respectively, compared with the control treatment [11]. The application of di-ammonium phosphate and single super phosphate at $50 \mathrm{~kg} \mathrm{P}$ $\mathrm{ha}^{-1}$ to the nursery produced the highest grain yields (4.9 $\mathrm{t} \cdot \mathrm{ha}^{-1}$ corresponding to a $21 \%$ increase over the control) [13]. In the case of poor soil fertility or during the dry season when initial growth is slower, top dressing of nitrogen at the rate of $10 \mathrm{~g}$ of urea per $\mathrm{m}^{2}$ about two weeks after sowing increases seedling vigour [9]. The application of farm yard manure (FYM) to the nursery is a widespread practice of Nepalese farmers but the application of inorganic fertilizers in the nursery is seldom practiced.

Similarly, timely planting and appropriate seedling age at transplanting can be an important and cheap practice for higher productivity in rice. The age of seedlings at transplanting is important because it is one factor determining the number of tillers produced per hill. It has a direct effect on plant height, effective tiller number, length of panicles, grains per panicle and other yield attributing characters. The many above- and below-ground characteristics of rice plants (seedling vigour), before and after transplanting, vary with seedling age, growing environment and seeding rate $[14,15]$. There was a positive impact on grain yield by using seedlings not older than 25 days [16]. Very young seedlings (around 14 days) are recommended in the System of Rice Intensification [17]. The use of 30 and 60 days old seedlings did not affect yield, and using 45 days old seedlings was proved to be better than those aged 30, 60 and 75 days [18,19]. BRRI has recommended seedling age of rice transplantation based on growing season, such as 20 - 30 days for the Aus season, 20 - 35 days for the T. Aman season and 40 45 days for the Boro season [20]. Tillering dynamics of the rice plant greatly depends on the age of seedling at transplanting and it was observed that 40 days old seedlings gave higher number of panicles per $\mathrm{m}^{2}$ than 20 or 60 days old seedlings [21]. A field experiment in Nepal including five different varieties with 25 and 50 days old seedlings results showed that 50 days old seedlings produced $153 \mathrm{~kg} \cdot \mathrm{ha}^{-1}$ higher grain yield $\left(2356 \mathrm{~kg} \cdot \mathrm{ha}^{-1}\right)$ compared to 25 days old seedling (2203 $\left.\mathrm{kg} \cdot \mathrm{ha}^{-1}\right)$ [22]. The grain yield decreases after transplanting younger seedlings (14 d), probably due to the higher mortality rate as compared with older seedlings (28 d) [23]. Transplanting of 30 days old seedlings gave higher grain yields than 45 and 60 days old seedlings [24]. Recent studies on SRI indicated that yield and yield components might be increased by transplanting seedlings as young as 14 days as compared with older seedlings (21 - 23 days) [25]. However, in tropical lowland rice, farmers transplant rice seedlings usually between 25 to 50 days after germination [26]. In Nepal, rice production generally depends on monsoon rain, the seedlings are transplanted only after sufficient rainfall for land preparation and planting has occurred. The seedling age in Pakistan mainly depends on the availability of water, labor, herbicides and other inputs and the majority of rice farmers have been seen to use higher seed rates then recommended and stated very high seeding densities in the rice nursery and the use of older seedlings for transplanting is a major reason of lower rice yield [27].

This overview allows two main conclusions: one is that appropriate seeding density, nursery management, and seedling age are obviously dependent on many factors and might vary in different production systems. The other is that farmers often do not seem to give nursery management sufficient attention, probably because the connection between nursery management and grain yield is rarely obvious. In addition, clear guidelines about proper nursery management in typical Nepalese rice production systems are lacking because they have not been identified. Therefore, our objective was to study the synergistic influence of different seedbed management practices on seedling characteristics and the consequent impact on plant growth and yield after transplanting in a typical rice environment of Nepal. Nursery management elements evaluated were the effect of nutrient management, different seeding densities and seedling age. The targeted outputs were nursery management guidelines for Nepalese rice farmers.

\section{Materials and Methods}

\subsection{Site Description}

The experimental site was located in the mid hills of Ne- 
pal, at Sundarbazar-8, Lamjung. The experiment was conducted in two different but neighboring farmers' fields ( $700 \mathrm{~m}$ asl, $28^{\circ} 7^{\prime} \mathrm{N}, 84^{\circ} 24^{\prime} \mathrm{E}$ ) during the 2009 and 2010 wet seasons. The widespread rice variety Radha- 4 was used which was released as a drought tolerant variety for rainfed lowlands. Before the experiment started, a field survey was conducted in Sundarbazar and Purkot villages of Lamjung and Tanahun district, respectively, to determine the seed rate used by the majority of farmers. Twenty farmers were selected randomly and requested to establish their dry bed nursery according to their own practice. The resulting average farmer's seed rate was $607 \mathrm{~g} \cdot \mathrm{m}^{-2}$ in the nursery bed. The rainy season lasts normally from June to September, and the highest rainfall amount occurs usually in June and July. The total seasonal rainfall at the research site was $912 \mathrm{~mm}$ and $1533 \mathrm{~mm}$ during the cropping season 2009 and 2010, respectively (Figure 1). The soil test results of the experimental sites in 2009 and 2010, respectively, were as follows: $\mathrm{pH} 6.36$ and 6.75 , organic carbon $1.74 \%$ and $1.58 \%$, total $\mathrm{N} 0.26 \%$ and $0.20 \%$, available P Olsen 7.3 and $7.3 \mathrm{mg} \mathrm{kg}^{-1}$, exchangeable potassium 0.43 and 0.28 cmol $+\mathrm{kg}^{-1}$, clay $17.5 \%$ and $17.5 \%$, sand $54.5 \%$ and $54.0 \%$, silt $28.0 \%$ and $28.5 \%$.

\subsection{Experimental Layout and Crop Management}

The experiment was conducted in a three factorial Randomized Complete Block Design with three replications and 8 treatments. The treatments were combined from three factors: Factor $\mathrm{F}$ was the fertilizer management, with farmer's practice $\mathrm{F}_{0}$ (FYM at $6 \mathrm{t} \cdot \mathrm{ha}^{-1}$ corresponding to $15: 30: 15 \mathrm{~kg} \mathrm{NPK} \mathrm{ha}^{-1}$ ) and the improved practice $\mathrm{F}_{1}$ (FYM at $6 \mathrm{t}^{\mathrm{F}} \mathrm{a}^{-1}+100 \mathrm{~kg}$ Ammonium phosphate sulphate [APS] ha ${ }^{-1}$ or 20:20:0:13 kg N, $\mathrm{P}_{2} \mathrm{O}_{5}, \mathrm{~K}_{2} \mathrm{O}$ and $\mathrm{SO}_{2}$ $\mathrm{ha}^{-1}$ top dressing at $15 \mathrm{DAS}$ ). The second factor was

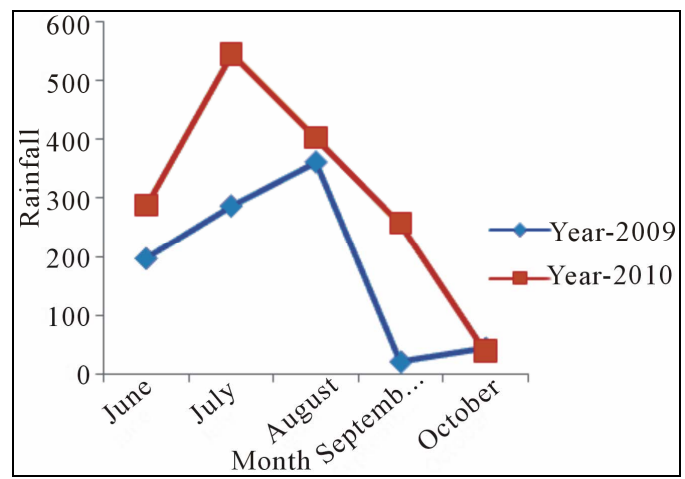

(a) seeding density (D), with farmers practice $\mathrm{D}_{1}(607 \mathrm{~g}$ seed per $\mathrm{m}^{2}$ of nursery area) and the improved practice $\mathrm{D}_{2}$ (303 g seed per $\mathrm{m}^{2}$ of nursery area). The last factor was the age of seedlings transplanted (A), with $\mathrm{A}_{1}$ (20 days old seedlings) and $\mathrm{A}_{2}$ (40 days old seedlings). Combinations of all the three experimental factors and resulting treatments are given in Table 1.

The rice variety Radha- 4 was used and raised in the nursery with the dry bed method. FYM at $6 \mathrm{t} \cdot \mathrm{ha}^{-1}$ was applied and incorporated during seed bed preparation. Dry seeds were broadcasted uniformly in the nursery. Seedlings were raised in 8 sub-plots of $1.5 \mathrm{~m}^{2}$ per plot for each treatment, 4 with the high $\left(D_{1}\right)$ and 4 with the low $\left(D_{2}\right)$ seeding density. Ammonium phosphate sulphate (APS) at $100 \mathrm{~kg} \cdot \mathrm{ha}^{-1}$ (corresponding to 20:20:0:13 $\mathrm{kg} \mathrm{N}, \mathrm{P}_{2} \mathrm{O}_{5}, \mathrm{~K}_{2} \mathrm{O}$ and $\mathrm{SO}_{2}$ ) were top dressed 15 days after seeding in the concerned four plots $\left(\mathrm{F}_{1}\right)$, none in the others $\left(\mathrm{F}_{0}\right)$. To produce young (20 days) and old (40 days) seedlings, two different seeding dates with a 20 days interval were used $\left(2^{\text {nd }}\right.$ and $4^{\text {th }}$ week of June).

In the main field, FYM was applied at 6 tons $\mathrm{ha}^{-1}$ just before field preparation and the basal dose of fertilizer at 30:40:20 kg N: $\mathrm{P}_{2} \mathrm{O}_{5}: \mathrm{K}_{2} \mathrm{O}$ ha $^{-1}$ was applied just before transplanting, using Urea, DAP and MOP. The wet soil was prepared by cultivating it two times with a desi plough, followed by one leveling. Seedlings were uprooted carefully and two seedlings per hill were transplanted into the puddled soil keeping row-to-row and plant-to-plant distances of $0.2 \mathrm{~m}$. The remaining $30 \mathrm{~kg} \mathrm{~N}$ $\mathrm{ha}^{-1}$ were applied in two equal splits at booting and panicle initiation. There was no assured irrigation facility and the crop was dependent on rainfall. Manual weeding was conducted at 25 and 50 days after transplanting. In both seasons, no other pests occurred, and no other plant protection measures were followed. Harvesting was done manually at the time of maturity, with an approximate

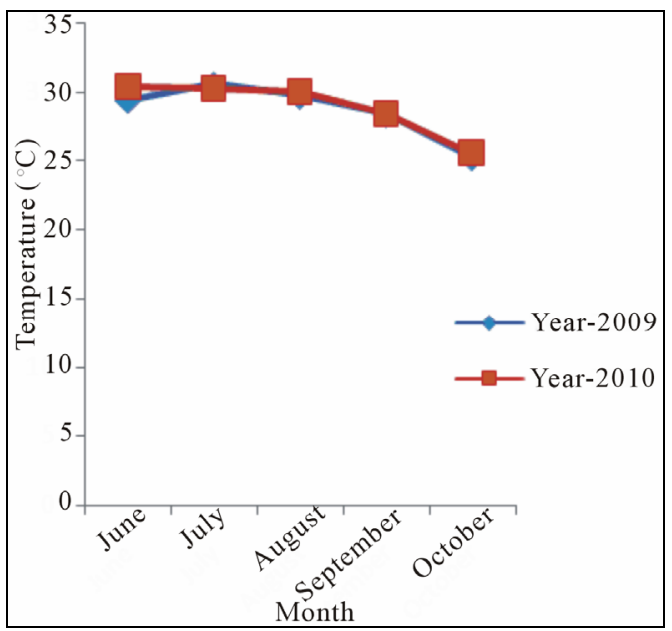

(b)

Figure 1. Rainfall and mean temperature at the experimental sites during the rice growing seasons. 
Table 1. Nursery treatment combinations in the experiment during 2009 and 2010.

\begin{tabular}{|c|c|c|c|c|}
\hline Treatment & Fertilizer used & Seed rate $\left(\mathrm{g} \cdot \mathrm{m}^{-2}\right)$ & Seedling age (days) & Factor combination \\
\hline $\mathrm{T}_{1}$ & $\mathrm{~F}_{0}(\mathrm{FYM})$ & $\mathrm{D}_{1}(607)$ & $\mathrm{A}_{1}(20)$ & $\mathrm{F}_{0} \mathrm{D}_{1} \mathrm{~A}_{1}$ \\
\hline $\mathrm{T}_{2}$ & $\mathrm{~F}_{0}(\mathrm{FYM})$ & $\mathrm{D}_{1}(607)$ & $\mathrm{A}_{2}(40)$ & $\mathrm{F}_{0} \mathrm{D}_{1} \mathrm{~A}_{2}$ \\
\hline $\mathrm{T}_{3}$ & $\mathrm{~F}_{0}(\mathrm{FYM})$ & $\mathrm{D}_{2}(303)$ & $\mathrm{A}_{1}(20)$ & $\mathrm{F}_{0} \mathrm{D}_{2} \mathrm{~A}_{1}$ \\
\hline $\mathrm{T}_{4}$ & $\mathrm{~F}_{0}(\mathrm{FYM})$ & $\mathrm{D}_{2}(303)$ & $\mathrm{A}_{2}(40)$ & $\mathrm{F}_{0} \mathrm{D}_{2} \mathrm{~A}_{2}$ \\
\hline $\mathrm{T}_{5}$ & $\mathrm{~F}_{1}(\mathrm{FYM}+\mathrm{APS})$ & $\mathrm{D}_{1}(607)$ & $\mathrm{A}_{1}(20)$ & $\mathrm{F}_{1} \mathrm{D}_{1} \mathrm{~A}_{1}$ \\
\hline $\mathrm{T}_{6}$ & $\mathrm{~F}_{1}(\mathrm{FYM}+\mathrm{APS})$ & $\mathrm{D}_{1}(607)$ & $\mathrm{A}_{2}(40)$ & $\mathrm{F}_{1} \mathrm{D}_{1} \mathrm{~A}_{2}$ \\
\hline $\mathrm{T}_{7}$ & $\mathrm{~F}_{1}(\mathrm{FYM}+\mathrm{APS})$ & $\mathrm{D}_{2}(303)$ & $\mathrm{A}_{1}(20)$ & $\mathrm{F}_{1} \mathrm{D}_{2} \mathrm{~A}_{1}$ \\
\hline $\mathrm{T}_{8}$ & $\mathrm{~F}_{1}(\mathrm{FYM}+\mathrm{APS})$ & $\mathrm{D}_{2}(303)$ & $\mathrm{A}_{2}(40)$ & $\mathrm{F}_{1} \mathrm{D}_{2} \mathrm{~A}_{2}$ \\
\hline
\end{tabular}

seed moisture content of $22 \%$. Threshing was done separately for each plot.

\subsection{Observations and Statistics}

Crop observations on growth stages were conducted during the season. Grain yield, plant height and yield components were determined at harvest following standard procedures. Collected data were analyzed statistically using MSTATC 1997. ANOVA was conducted to test the significance of differences for each parameter. The least significant difference (LSD) at 5\% probability was used to compare treatment means [28]. Duncans Multiple Range Test (DMRT) was used to find the range between the tested treatments.

The cost of cultivation for individual treatments was calculated on the basis of input and service costs in the local markets. The gross return was calculated using local market prices $\left(\mathrm{Rs} \cdot \mathrm{ha}^{-1}\right)$ of the outputs, based on field survey results during 2009 and 2010 at the study site. The net return was calculated by deducting the cost of cultivation from the gross return. The benefit/cost ratio was calculated according to: $\mathrm{B} / \mathrm{C}$ ratio $=$ gross return $/$ cost of cultivation.

\section{Results and Discussion}

\subsection{Plant Height}

Plant height is an important plant trait that is controlled by the genetic make-up of the plant as well as the growing conditions, seedling vigour and nutrient status [29]. Table 2 shows that there is no significant effect of fertilizer management on plant height whereas seeding density and seedling age had a significant effect but only in the 2009 season. The average plant height was much lower in 2009 (0.74 $\mathrm{m}$ verses $1.16 \mathrm{~m}$ in 2010), due to late transplanting $\left(6^{\text {th }}\right.$ August $)$, less rainfall, and a long drought phase during the cropping season. The lower seeding density caused taller plants in 2009 but had no significant effect in the second year. Similarly, the older seedling (40-d) result in taller plants in 2009 but the effect was not significant in 2010. These results are supported by Khatun et al. who observed taller plants after transplanting older seedlings (45 days as compared with 30 days old seedlings) in boro rice, and by Ashraf et al. who used 35 and 25 days old seedlings [19,30]. All three management factors had a significant interaction on plant height in 2009 but not in 2010 . The positive effect of low seeding density and fertilizer top dressing is of course due to less competition and better plant nutrition, and older seedlings seemed to provide an additional advantage in the drier 2009 season. We did not see a strong effect of fertilizer management in contrast to Mishra and Salokhe, who observed that fertilizer application in the nursery was a crucial factor in increasing seedling vigor [31]. Similarly Farooq et al. also found an increasing trend of plant height after transplanting improved nursery seedlings [32]. The fact that the wet conditions in 2010 obviously caused maximal height in all treatments indicates that nursery treatment might be more important in stress conditions.

\subsection{Productive Tillers}

Fertilizer management in the nursery had a statistically significant effect on productive tiller number in 2009 but not in 2010 , although better plant nutrition in the nursery increased the productive tiller number in both years (Table 2). Significant effects on productive tiller number were also found for seeding density. In both years more productive tillers (290 vs 277 in 2009) and (306 vs 296 in 2010) were observed with the use of low seeding density versus high seeding density in both years. The result of more productive tillers after the use of low seeding density in the nursery are most likely due to lower seedling competition for nutrient, light and space resulting in more vigorous seedlings. In the low-density nursery, tiller formation started in the nursery itself, especially when older seedlings (40 days) were used, whereas no tillers formed in the high-density nursery. Statistically 
Table 2. Effect of nursery fertilizer management, seeding density and seedling age on growth and yield attributes of rice in the 2009 and 2010 wet seasons.

\begin{tabular}{|c|c|c|c|c|c|c|}
\hline \multirow{2}{*}{ Treatments } & \multicolumn{2}{|c|}{ Plant height $(\mathrm{cm})$} & \multicolumn{2}{|c|}{ Productive tillers $\mathrm{m}^{-2}$} & \multicolumn{2}{|c|}{ Filled grains panicle ${ }^{-1}$} \\
\hline & 2009 & 2010 & 2009 & 2010 & 2009 & 2010 \\
\hline \multicolumn{7}{|c|}{ A. Fertilizer management: } \\
\hline $\mathrm{F}_{0}(\mathrm{FYM})$ & 74 & 117 & 275 & 298 & 86.7 & 118 \\
\hline $\mathrm{F}_{1}(\mathrm{FYM}+\mathrm{APS})$ & 75 & 116 & 292 & 304 & 93.0 & 122 \\
\hline F test & NS & NS & S & NS & S & NS \\
\hline \multicolumn{7}{|c|}{ B. Seeding density: } \\
\hline$D_{1}\left(607 \mathrm{~g} \cdot \mathrm{m}^{-2}\right)$ & 73 & 116 & 277 & 296 & 89.0 & 117 \\
\hline$D_{2}\left(303 \mathrm{~g} \cdot \mathrm{m}^{-2}\right)$ & 76 & 116 & 290 & 306 & 90.6 & 123 \\
\hline F test & $\mathrm{S}$ & NS & S & S & NS & NS \\
\hline \multicolumn{7}{|c|}{ C. Age of seedling: } \\
\hline $\mathrm{A}_{1}$ (20 days) & 72 & 117 & 264 & 295 & 80.7 & 117 \\
\hline $\mathrm{A}_{2}$ (40 days) & 77 & 116 & 303 & 307 & 98.9 & 122 \\
\hline F test & $\mathrm{S}$ & NS & S & S & S & NS \\
\hline Interaction $(\mathrm{A} \times \mathrm{B} \times \mathrm{C})$ & $\mathrm{S}$ & NS & NS & S & S & NS \\
\hline S.E $( \pm)$ & 0.50 & - & 4.23 & 4.74 & 1.35 & - \\
\hline $\mathrm{CD}$ (at $5 \%$ ) & 1.06 & - & 9.08 & 10.17 & 2.90 & - \\
\hline $\mathrm{CV} \%$ & 1.64 & 2.00 & 3.66 & 3.86 & 3.69 & 7.10 \\
\hline Grand mean & 74.3 & 116.3 & 283.8 & 301.0 & 89.8 & 120.0 \\
\hline
\end{tabular}

significant differences in productive tiller number were also caused by the seedling age. Older seedlings produced more productive tillers compared with younger seedlings in both years (303 vs 264 in 2009; 307 vs 295 tillers in 2010). Similar results were described by Mobasser et al., who also observed that older seedlings (45 days) produced more productive tillers $\left(355 \mathrm{~m}^{-2}\right)$ compared with younger seedlings [33]. Rashid et al. also reported that the tillering dynamics of rice plants greatly depends on the seedling age at transplanting, and also observed that 40 days old seedlings gave a higher panicle number per $\mathrm{m}^{2}$ than 20 or 60 days old seedlings [21]. Similar results were mentioned by Channabasappa et al. According to their study, 35 and 45 days old seedlings performed significantly better with respect to tiller number and grains per panicle than 25 days old seedlings [34].

Regarding the interaction effect of fertilizer management and age of seedlings on productive tiller number, no significant effect was found in 2009 but a significant effect occurred in 2010. As the Figure 2 shows, topdressing of APS fertilizer $\left(\mathrm{F}_{1}\right)$ increased the productive tiller number in all cases except for young seedlings in 2010. Again this indicates the bigger importance of good nursery management in the drier, more stressful 2009 season. Alam et al. also found that 35 days old seedlings performed better than 28 or 21 days old seedlings regarding the number of tillers hill ${ }^{-1}$, the number of effective tillers hill ${ }^{-1}$, grain yield and straw yield in the main field [35]. The older seedlings recovered faster from the transplanting shock, possibly due to the higher nitrogen content, although usually younger plants are assumed to faster resume the rate of phyllochron development [36].

\subsection{Filled Grains, Unfilled Grains and Sterility}

An important yield component is the number of filled grains per panicle. Statistically significant effects on the number of filled grains were only found in the 2009 season, and were due to fertilizer management and seedling age (Table 2 and Figure 3). Although there were significant interaction effects of all three factors in the 2009 season, Figure 3 indicates a generally positive effect of better fertilizer management and older seedlings. Moreover, the number of filled grains per panicle was higher in the wetter year 2010 than in the drier year 2009. Khatun et al. reported similar results and found that the number of filled grains per panicle during the main season experiment was highest for 45 days old seedlings compared with 30,60 and 75 days old seedlings [19].

In the 2009 season, the number of unfilled grains per panicle was significantly affected by fertilizer management and seedling age, but not by seeding density (Table 


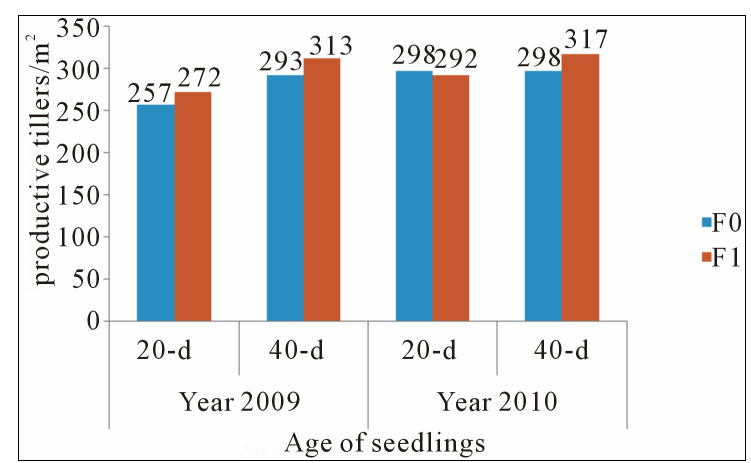

Figure 2. Interaction effect of fertilizer management in the nursery and seedling age on productive tiller number in the experimental seasons 2009 and 2010.

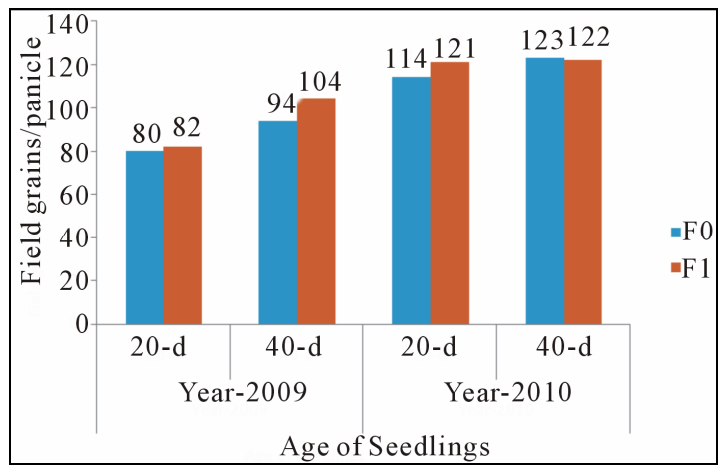

Figure 3. Interaction effect of fertilizer management in the nursery and seedling age on the number of filled grains per panicle in the experimental seasons 2009 and 2010.

3). No significant effect by any factor could be detected in 2010. Top dressing of APS in the seedbed reduced the number of unfilled grains. Consequently, improved fertilizer management reduced the sterility percentage but this effect was non-significant in both years. Similarly, low seeding density and older seedlings always reduced the number of unfilled grains and spikelet sterility but the effect was small and often non-significant. A decrease of spikelet sterility with transplanting of older seedlings was also reported by Murty and Saha [37].

Across treatments, the number of unfilled grains and spikelet sterility was higher in 2009 , and the number of filled grains was higher in 2010. This was obviously caused by the late transplanting in 2009 ( $6^{\text {th }}$ August $)$, and the lower rainfall and longer drought phase in the same year.

\subsection{Grain Yield, Straw Yield and Harvest Index}

In both experimental years, fertilizer management in the nursery had no statistically significant effect on grain yield (Table 4). In contrast, the lower seeding density increased grain yield significantly in the 2009 season. And older seedlings had a highly significant and positive effect on grain yield in both years. The older seedlings increased grain yield by $0.7 \mathrm{t} \cdot \mathrm{ha}^{-1}$ in 2009 and still by 0.3 th ha ${ }^{-1}$ in 2010 . Older seedlings gave higher yields in most treatment combinations and this effect was much stronger in the drier season 2009. These results are agreed with Bhagat et al. who found that 40 days old seedlings produced higher grain yields as compared to 30 , 50, and 60 days old seedlings [38]. However, it must be noted that in our case older seedlings were seeded 20 days ahead (but transplanted at the same time as young seedlings), therefore also flowering and ripening slightly earlier than the treatments using younger seedlings. But the results indicate clearly that up to 40 days old seedlings of Radha-4 can be used without affecting the grain yield negatively, or with even positive yield gains.

The interaction between seeding density and seedling age on grain yield did not indicate significant differences in 2009, while significant differences were found in 2010 (Table 4 and Figure 4). Both factors were clearly additive in 2009 but the additive value was too small in 2010, causing this result. The combination of low seeding density and 40-d old seedlings produced the maximum grain yield in 2009 (2.86 tha $\mathrm{h}^{-1}$, or $34 \%$ above the mean of the experiment) and in $2010\left(7.05 \mathrm{t} \cdot \mathrm{ha}^{-1}\right.$, or $5 \%$ above the mean of the experiment). Again this shows clearly the higher importance and bigger effect of good seedbed management and seedling age in stressed environments.

With regards to straw yield, significant treatment effects were only observed for fertilizer management in the 2010 season, and for seedling age in the 2009 season. Across treatments, the average straw yield almost doubled in 2010 compared with 2009, but this relative increase was less than observed for grain yield. Consequently, the average harvest index increased dramatically from $2009(27 \%)$ to $2010(40 \%)$. The treatment effect on harvest index was mostly significant except for fertilizer management in 2009 and seeding density in 2010.

\subsection{Economic Analysis}

General costs of crop production were calculated on the basis of the prices found in the field survey at the study

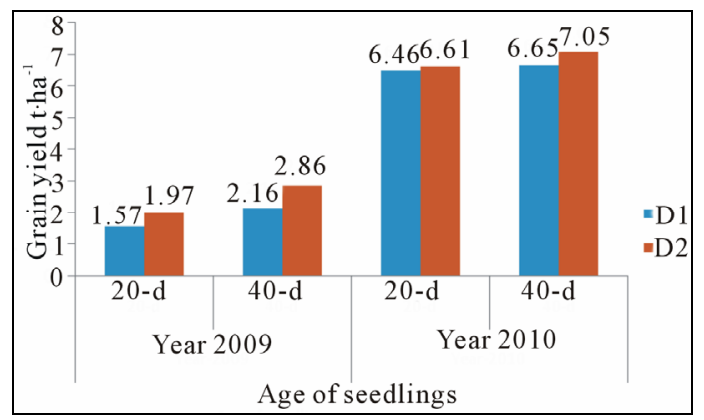

Figure 4. Interaction effect of seeding density and seedling age on grain yield in the experimental season 2009 and 2010. 
Table 3. Effect of nursery fertilizer management, seeding density and seedling age on unfilled grains and sterility of rice in the 2009 and 2010 wet seasons.

\begin{tabular}{|c|c|c|c|c|}
\hline \multirow{2}{*}{ Treatments } & \multicolumn{2}{|c|}{ Unfilled grains panicle $^{-1}$} & \multicolumn{2}{|c|}{ Spikelet sterility (\%) } \\
\hline & 2009 & 2010 & 2009 & 2010 \\
\hline \multicolumn{5}{|c|}{ A. Fertilizer management: } \\
\hline $\mathrm{F}_{0}(\mathrm{FYM})$ & 22 & 16 & 19.0 & 12.2 \\
\hline $\mathrm{F}_{1}(\mathrm{FYM}+\mathrm{APS})$ & 20 & 15 & 18.8 & 10.7 \\
\hline F test & S & NS & NS & NS \\
\hline \multicolumn{5}{|c|}{ B. Seeding density: } \\
\hline$D_{1}\left(607 \mathrm{~g} \cdot \mathrm{m}^{-2}\right)$ & 21 & 16 & 19.5 & 12.2 \\
\hline $\mathrm{D}_{2}\left(303 \mathrm{~g} \cdot \mathrm{m}^{-2}\right)$ & 20 & 15 & 18.3 & 10.7 \\
\hline F test & NS & NS & S & NS \\
\hline \multicolumn{5}{|c|}{ C. Age of seedling: } \\
\hline $\mathrm{A}_{1}$ (20 days) & 22 & 16 & 21.4 & 12.0 \\
\hline $\mathrm{A}_{2}$ (40 days) & 19 & 15 & 16.4 & 10.9 \\
\hline F test & S & NS & S & NS \\
\hline Interaction $(\mathrm{A} \times \mathrm{B} \times \mathrm{C})$ & NS & NS & NS & NS \\
\hline $\operatorname{S.E}( \pm)$ & 0.78 & - & 0.5 & - \\
\hline $\mathrm{CD}($ at $5 \%)$ & 1.68 & - & 1.07 & - \\
\hline $\mathrm{CV} \%$ & 9.29 & 15.43 & 6.48 & 14.96 \\
\hline Grand mean & 20.7 & 15.6 & 18.9 & 11.4 \\
\hline
\end{tabular}

site, conducted during 2009 and 2010. A total of 75742 rupees per hectare was the actual average cost of rice production in the mid hills during 2009 and 2010. Treatment dependent costs of cultivation were calculated on the basis of the additional inputs needed (Table 5). Statistically significant differences of the B:C ratios were found, and the treatments $T_{8}$ and $T_{4}$ showed the highest benefit (B:C ratio of 1.74 for both). The calculated $\mathrm{B}: \mathrm{C}$ ratios showed that all treatment combinations had a $\mathrm{B}: \mathrm{C}$ ratio above $1: 1.5$ except $T_{1}$ (1.47). A benefit cost (B:C) value greater than 2 is considered safe, indicating that the farmers get 2 Rs. for every rupee invested [24]. However, a minimum benefit cost ratio above 1.5 has been considered economically viable for an agricultural enterprise, especially if the investments costs are small [25]. Thus, the results in Table 5 indicate that all tested treatments except $T_{1}$ were economically viable. However, the actual net returns show that some treatments were much more profitable than others without substantial differences in the cost of production.

\section{Conclusion}

The overall objectives of this study were to investigate if some seedbed management options could improve grain yield in the main field, especially in the case of drought stress, of course without affecting crop performance in good years. Drought occurred only in 2009 whereas the high yields in 2010 indicated very favorable conditions for crop growth and yield in that season. The results confirmed that the options tested were able to increase grain yield considerable, especially in the drought year 2009 . Of the management factors tested, inorganic fertilizer in the seedbed had no consistent effect, whereas older seedlings and lower seeding density gave regularly higher yields, and the treatments that combined lower seeding rates and older seedlings achieved the highest grains yields and benefited cost ratio in both years. The treatments tested were realistic, cheap, and can be used by any rice farmer in the mid hills of Nepal. However, it must be noted that these results may be variety specific (only the variety "Radha-4" was used in both seasons and all treatments) and further studies are needed to confirm the results for other, widely used varieties in the region.

\section{Acknowledgements}

This study was supported by the Bill \& Melinda Gates Foundation through the project "Stress-Tolerant Rice for Poor Farmers in Africa and South Asia (STRASA), Phase 
Table 4. Effect of nursery fertilizer management, seeding density and seedling age on grain yield, straw yield and harvest index of rice during 2009 and 2010.

\begin{tabular}{|c|c|c|c|c|c|c|}
\hline \multirow{2}{*}{ Treatments } & \multicolumn{2}{|c|}{ Grain yield $\left(\mathrm{t} \cdot \mathrm{ha}^{-1}\right)$} & \multicolumn{2}{|c|}{ Straw yield $\left(\mathrm{t} \cdot \mathrm{ha}^{-1}\right)$} & \multicolumn{2}{|c|}{ Harvest index (\%) } \\
\hline & 2009 & 2010 & 2009 & 2010 & 2009 & 2010 \\
\hline \multicolumn{7}{|c|}{ A. Fertilizer top dressing in nursery } \\
\hline $\mathrm{F}_{0}(\mathrm{FYM})$ & 2.09 & 6.69 & 5.58 & 9.70 & 27 & 41 \\
\hline $\mathrm{F}_{1}(\mathrm{FYM}+\mathrm{APS})$ & 2.20 & 6.70 & 5.75 & 10.39 & 27 & 39 \\
\hline F test & NS & NS & NS & $\mathrm{S}$ & NS & S \\
\hline \multicolumn{7}{|c|}{ B. Seeding density } \\
\hline $\mathrm{D}_{1}\left(607 \mathrm{~g} \cdot \mathrm{m}^{-2}\right)$ & 1.87 & 6.63 & 5.60 & 10.05 & 25 & 40 \\
\hline$D_{2}\left(303 \mathrm{~g} \cdot \mathrm{m}^{-2}\right)$ & 2.42 & 6.76 & 5.73 & 10.04 & 29 & 40 \\
\hline F test & $\mathrm{S}$ & NS & NS & NS & $\mathrm{S}$ & NS \\
\hline \multicolumn{7}{|l|}{ C. Age of seedling } \\
\hline $\mathrm{A}_{1}$ (20 days) & 1.78 & 6.54 & 5.42 & 9.94 & 25 & 39 \\
\hline $\mathrm{A}_{2}$ (40 days) & 2.51 & 6.85 & 5.91 & 10.15 & 30 & 41 \\
\hline F test & $\mathrm{S}$ & $\mathrm{S}$ & $\mathrm{S}$ & NS & $\mathrm{S}$ & $\mathrm{S}$ \\
\hline Interaction $(\mathrm{A} \times \mathrm{B} \times \mathrm{C})$ & NS & NS & NS & $\mathrm{S}$ & NS & NS \\
\hline S. Ed. $( \pm)$ & 0.1 & 0.09 & 0.11 & - & 1.19 & 0.59 \\
\hline $\mathrm{CD}($ at $5 \%)$ & 0.21 & 0.20 & 0.25 & - & 2.55 & 1.25 \\
\hline $\mathrm{CV} \%$ & 11.39 & 3.52 & 5.05 & 4.37 & 10.79 & 4.02 \\
\hline Grand mean & 2.14 & 6.70 & 5.66 & 10.04 & 27.1 & 40.1 \\
\hline
\end{tabular}

Table 5. Economic analysis and benefit/cost (B:C) ratio based on the treatment-dependent costs of cultivation and the yielddependent net benefits during 2009 and 2010.

\begin{tabular}{|c|c|c|c|c|c|}
\hline Treatment & Treatment combination & Cost of cultivation $\left(\mathrm{Rs} \cdot \mathrm{ha}^{-1}\right)$ & Gross return $\left(\mathrm{Rs} \cdot \mathrm{ha}^{-1}\right)$ & Net return (Rs.ha ${ }^{-1}$ ) & $\mathrm{B}: \mathrm{C}$ ratio \\
\hline $\mathrm{T}_{1}$ & $\mathrm{~F}_{0}+\mathrm{D}_{1}+\mathrm{A}_{1}$ & 77868 & $114888^{\mathrm{e}}$ & $37020^{\mathrm{e}}$ & $1.47^{\mathrm{e}}$ \\
\hline $\mathrm{T}_{2}$ & $\mathrm{~F}_{0}+\mathrm{D}_{1}+\mathrm{A}_{2}$ & 77868 & $126492^{b}$ & $48623^{b}$ & $1.63^{\mathrm{b}}$ \\
\hline $\mathrm{T}_{3}$ & $\mathrm{~F}_{0}+\mathrm{D}_{2}+\mathrm{A}_{1}$ & 77868 & $116347^{\mathrm{de}}$ & $38478^{\mathrm{de}}$ & $1.50^{\mathrm{de}}$ \\
\hline $\mathrm{T}_{4}$ & $\mathrm{~F}_{0}+\mathrm{D}_{2}+\mathrm{A}_{2}$ & 77868 & $135390^{\mathrm{a}}$ & $57522^{\mathrm{a}}$ & $1.74^{\mathrm{a}}$ \\
\hline $\mathrm{T}_{5}$ & $\mathrm{~F}_{1}+\mathrm{D}_{1}+\mathrm{A}_{1}$ & 78018 & $119226^{\mathrm{cd}}$ & $41213^{\text {cd }}$ & $1.53^{\mathrm{cd}}$ \\
\hline $\mathrm{T}_{6}$ & $\mathrm{~F}_{1}+\mathrm{D}_{1}+\mathrm{A}_{2}$ & 78018 & $121290^{\mathrm{c}}$ & $43276^{c}$ & $1.55^{\mathrm{c}}$ \\
\hline $\mathrm{T}_{7}$ & $\mathrm{~F}_{1}+\mathrm{D}_{2}+\mathrm{A}_{1}$ & 78018 & $120345^{\mathrm{c}}$ & $42331^{\mathrm{c}}$ & $1.54^{\mathrm{c}}$ \\
\hline $\mathrm{T}_{8}$ & $\mathrm{~F}_{1}+\mathrm{D}_{2}+\mathrm{A}_{2}$ & 78018 & $136027^{\mathrm{a}}$ & $58013^{\mathrm{a}}$ & $1.74^{\mathrm{a}}$ \\
\hline \multicolumn{2}{|r|}{ S. Ed. $( \pm)$} & & 4244.5 & 4244.5 & 0.054 \\
\hline \multicolumn{2}{|r|}{$\mathrm{CD}($ at $5 \%)$} & & 8617 & 8617 & 0.11 \\
\hline \multicolumn{2}{|r|}{$\mathrm{CV} \%$} & & 6.24 & 17.46 & 6.23 \\
\hline \multicolumn{2}{|r|}{ Grand mean } & & 123751 & 45810 & 1.59 \\
\hline
\end{tabular}

Phase 1" and the International Fund for Agricultural Development through the project "Enabling Poor Rice Farmers to Improve Livelihoods and Overcome Poverty in South and Southeast Asia through the Consortium for Unfavorable Rice Environments (CURE)".

\section{REFERENCES}

[1] NARC, "Research Highlights: 2002/03-2006/07," Communication, Publication and Documentation Division, Nepal Agricultural Research Council (NARC), Lalitpur, 2007, p. 17. 
[2] MOAC, "Statistical Information on Nepalese Agriculture," Ministry of Agriculture and Co-Operatives, AgriBusiness Promotion and Statistics Division, Singha Durbar, Kathmandu, 2012.

[3] MOAC, "Statistical Information on Nepalese Agriculture," Ministry of Agriculture and Co-Operatives, AgriBusiness Promotion and Statistics Division, Singha Durbar, Kathmandu, 2010.

[4] MOAC, "Statistical Information on Nepalese Agriculture," Ministry of Agriculture and Co-Operatives, AgriBusiness Promotion and Statistics Division, Singha Durbar, Kathmandu, 2009.

[5] M. Lal and R. K. Roy, "Effect of Nursery Seeding Density and Fertilizer on Seedling Growth and Yield of Rice," Indian Journal of Agronomy, Vol. 41, No. 1, 1996, pp. 642-644.

[6] B. B. Adhikari, "Contribution of Germplasm and Management Options to System Productivity of Rainfed Rice in the Mid Hills of Nepal," Ph.D. Thesis, Sam Higginbottom Institute of Agriculture, Technology and Sciences, Allahabad, 2013.

[7] O. P. Singh, D. Pal and H. Om, "Effect of Seed Rate in Nursery and Seedlings per Hill on the Yield of Transplanted Rice," Indian Journal of Agronomy, Vol. 32, 1987, pp. 96-97.

[8] M. M. Panda, M. D. Reddy and A. R. Sharma, "Yield Performance of Rainfed Lowland Rice as Affected by Nursery Fertilizer under Conditions of Intermediate Deepwater $(15-50 \mathrm{~cm})$ and Flash Floods," Plant and Soil, Vol. 132, No. 1, 1991, pp. 65-71.

http://dx.doi.org/10.1007/BF00011013

[9] M. C. S. Wopereis, M. J. Kropff and A. R. Maligaya, "The Seedling Nursery," PLAR-IRM Curriculum: Technical Manual, 2009, pp. 45-48.

[10] K. N. Singh, B. Hassan, B. A. Kanday and A. K. Bhat, "Effect of Nursery Fertilization on Seedling Growth and Yield of Rice," Indian Journal of Agronomy, Vol. 50, No. 3, 2005, pp. 187-189.

[11] C. Ros, R. W. Bell and P. F. White, "Effect of Nursery Applications of N and P on Rice Yield," Kasetsart Journal: Natural Science, Vol. 31, 1997, pp. 96-105.

[12] C. V. Raghavaiah, B. C. Ghosh and M. K. Jana, "Nursery Management for Rice Grown in Intermediate Deep Water," IRRN, Vol. 14, 1989, pp. 31-32.

[13] S. Rajagopahan and J. Krishnarajan, "Effect of Nursery Management Technique on Phosphorus Nutrition of Rice in Main Field," Oryza, Vol. 24, 1987, pp. 199-209.

[14] M. Himeda, "Cultivation Technique of Rice Nursing Seedlings: Review of Research Papers and Its Future Implementation," Agriculture and Horticulture, Vol. 69, 1994, pp. 679-683.

[15] R. Sasaki, "Characteristics and Seedlings Establishment of Rice Nursling Seedlings," Japanese Agricultural Research Quarterly, Vol. 38, No. 1, 2004, pp. 7-13.

[16] K. Thanunathan and V. Sivasubramanian, "Age of Seedling and Crop Management Practices for High Density (HD) Grain in Rice," Crop Research, Vol. 24, No. 3, 2002, pp. 421-424.
[17] H. Delaulanié, "Intensive Rice Farming in Madagascar. English Translation of the 1993 Publication," Tropicultura, Vol. 29, No. 3, 2011, pp. 183-187.

[18] D. Chandra and G. B. Manna, "Effect of Planting Date, Seedling Age and Planting Density in Late Planted Wet Season Rice," International Rice Research Notes (IRRN), Vol. 13, No. 6, 1988, p. 30.

[19] A. Khatun, M. I. U. Mollah, I. H. Rashid, M. S. Islam and A. H. Khan, "Seasonal Effect of Seedling Age on the Yield of Rice," Pakistan Journal of Biological Sciences, Vol. 5, No. 1, 2002, pp. 40-42. http://dx.doi.org/10.3923/pjbs.2002.40.42

[20] BRRI, “Annual Report for 1990,” Bangladesh Rice Research Institure, Joydebpur, Gazipur, Vol. 329, 1992.

[21] M. A. Rashid, M. L. Argon and G. L. Denning, "Influence of Variety, Seedling Age and Nitrogen on Growth and Yield of Rice Grown on Saline Soil," Bangladesh Rice Journal, Vol. 1, No. 1, 1990, pp. 37-47.

[22] M. L. Shahi and R. B. Yadav, "Response of Rice Varieties to Age of Seedlings and Transplanting Dates," Nepal Agriculture Research Journal, Vol. 4, 2000/2001, pp. 1417.

[23] M. L. Kewat, S. B. Agrawal, K. K. Agrawal and R. S. Sharma, "Effect of Divergent Plant Spacing and Age of Seedlings on Yield and Economics of Hybrid Rice (Oryza sativa L.)," Indian Journal of Agronomy, Vol. 47, 2002, pp. 367-371.

[24] K. S. Reddy and B. B. Reddy, "Effect of Transplanting Time, Plant Density and Seedling Age on Growth and Yield of Rice," Indian Journal of Agronomy, Vol. 37, 1992, pp. 18-21.

[25] A. K. Makarim, V. Balasubramanian, Z. Zaini, I. Syamsiah, I. G. P. A. Diratmadja and A. Handoko, "Systems of Rice Intensification (SRI): Evaluation of Seedling Age and Selected Components in Indonesia," In: B. A. M. Bouman, A. Hengsdijk, B. Hardy, P. S. Bindraban, T. P. Tuong and J. K. Ladha, Eds., International Workshop on Water-Wise Rice Production, Los Baños, 8-11 April 2002, International Rice Research Institute (IRRI), pp. 129-139.

[26] R. S. Singh and S. B. Singh, "Effect of Age of Seedlings, N-Levels and Time of Application on Growth and Yield of Rice under Irrigated Condition," Oryza, Vol. 36, No. 4, 1999, pp. 351-354.

[27] N. Sarwa, M. Maqsood, S. A. Wajid and M. Anwarul-Haq, "Impact of Nursery Seeding Density, Nitrogen and Seedling Age on Yield and Yield Attributes of Fine Rice," Chilean Journal of Agricultural Research, Vol. 71, No. 3, 2011, pp. 343-349. http://dx.doi.org/10.4067/S0718-58392011000300001

[28] R. G. Steel, D. Torrie and J. H. Torrie, "Principles and Procedure of Statistics," Mc Graw Hill Book Co. Inc., New York, 1980, pp. 187-188.

[29] S. Yoshida, "Mineral Nutrient of Rice: In Fundamentals of Rice Crop Science," IRRI, Los Banos, 1981, pp. 111146.

[30] M. Ashraf, A. Khalid and K. Ali, "Effect of Seedling Age and Density on Growth and Yield of Rice in Saline Soil," Pakistan Journal of Biological Sciences, Vol. 2, No. 3, 
1999, pp. 860-862.

http://dx.doi.org/10.3923/pjbs.1999.860.862

[31] A. Mishra and V. M. Salokhe, "Seedling Characteristics and the Early Growth of Transplanted Rice under Different Water Regimes," Experimental Agriculture, Vol. 44, No. 3, 2008, pp. 365-383.

http://dx.doi.org/10.1017/S0014479708006388

[32] M. Farooq, S. M. A. Basra and N. Ahmad, "Improving the Performance of Transplanted Rice by Seed Priming," Plant Growth Regulation, Vol. 51, No. 2, 2007, pp. 129137. http://dx.doi.org/10.1007/s10725-006-9155-x

[33] H. R. Mobasser, D. B. Tari, V. Muhammad, R. S. Abadi and E. Ali, "Effect of Seedling Age and Planting Space on Yield and Yield Components of Rice (Neda Variety)," Asian Journal of Plant Sciences, Vol. 6, No. 2, 2007, pp. 438-440. http://dx.doi.org/10.3923/ajps.2007.438.440

[34] K. S. Channabasappas, B. G. Masthana, S. G. Patil and D. K. Masthana, "Response of Late Transplanted Rice (Oryza sativa) to Age, Number of Seedlings and Fertilizer Levels," Indian Journal of Agronomy, Vol. 43, 1998, pp. 636-638.
[35] M. Z. Alam, M. Ahmed, M. S. Alam, M. E. Haque and M. S. Hossin, "Performance of Seedling Ages and Seedling Raising Techniques on Yield and Yield Components of Transplant Aman Rice," Pakistan Journal of Biological Sciences, Vol. 5, No. 11, 2002, pp. 1214-1216. http://dx.doi.org/10.3923/pjbs.2002.1214.1216

[36] Anonymous, "The System of Rice Intensification-SRI, Variations in SRI Practices (2004),” 2007. http://ciifad.cornell.edu/sri/variation.html

[37] K. S. Murty and G. Saha, "Effect of Age of Seedlings at Normal Transplanting on Growth and Yield of Rice Varieties," Indian Journal of Agricultural Sciences, Vol. 49, 1979, pp. 797-801.

[38] K. L. Bhagat, A. K. Daham, H. Singh and B. S. Azad, "Influence of Seedling Age at Transplanting on Growth and Yield of Basmati Rice," Annals of Agricultural Research, Vol. 12, No. 3, 1991, pp. 249-254.

[39] A. S. Bhandari, "Sustainability Measures of Rice-Wheat System across Agro-Ecological Regions in Nepal," Ph.D. Thesis, Central, Luzon State University, Munz, 1993. 